\title{
Orbital Abscess after Facial Trauma
}

\author{
Elis Cristina Sousa SERRA \\ Cassio Edvard SVERZUT \\ Alexandre Elias TRIVELLATO \\ Department of Oral and Maxillofacial Surgery and Periodontology, Ribeirão Preto Dental School, \\ University of São Paulo, Ribeirão Preto, SP, Brazil
}

\begin{abstract}
This paper reports a rare case of acute severe orbital abscess manifested 2 days after a facial trauma without bone fracture in a 20 -year-old Afro-American female. The symptoms worsened within the $24 \mathrm{~h}$ prior to hospital admission resulting in visual disturbances such as diplopia and photophobia. The clinical findings at the first consultation included fever, periorbital swelling and redness, ptosis, proptosis and limitation of ocular movements upwards, downwards, to the right and to the left. Computed tomography scan showed proptosis with considerable soft tissue swelling on the left side and no fracture was evidenced in the facial skeleton, including the zygomatic-orbital complex. After hospital admission and antibiotic therapy intravenously the patient was conducted to the operation room and submitted to incision and drainage under general anesthesia. The orbit was approached thorough both eyelids and the maxillary sinus was reached only through the Caldwell-Luc approach. The postoperative period was uneventful and the rapid improvement of symptoms was remarkable. Visual acuity and ocular motility returned to the normal ranges within 2 days after the surgical intervention. After 12 postoperative days, the patient presented with significative improvement in the ptosis and proptosis, and acceptable scars.
\end{abstract}

Key Words: facial trauma, zygomatic-orbital complex, orbital abscess.

\section{INTRODUCTION}

Orbital cellulitis and abscess have been described in the literature as complication that usually occur secondary to infection in the maxillary, ethmoidal and frontal sinuses (1-3). Other causes include scarlet fever, trauma to neighboring tissue, odontogenic abscess, middle ear infections, and intracranial infection (4-6). Orbital infections of odontogenic origin are the rarest sequelae, with a prevalence of $1.3 \%$ (3).

Correct diagnosis, adequate antibiotic therapy, and surgical drainage are the keys to the success (3). Delay in diagnosis can result in serious sequelae such as blindness, cavernous sinus thrombosis, meningitis, cerebral abscess, and death $(7,8)$.

This paper presents a rare case of acute severe orbital abscess manifested 2 days after a facial trauma without fracture of the zygomaticorbital complex.

\section{CASE REPORT}

A20-year-old Afro-American female presented to the Oral and Maxillofacial Surgery Division of the Santa Casa Hospital of Ribeirão Preto, SP, Brazil complaining of orbital swelling and pain on the left side (Fig. 1). These symptoms had started 2 days earlier and worsened within the $24 \mathrm{~h}$ prior to hospital admission resulting in visual disturbances such as diplopia and photophobia. The clinical findings at the consultation included fever, periorbital swelling and redness, ptosis, proptosis and limitation of ocular movements upward, downward, right and left (Fig. 2).

The patient reported facial trauma that occurred in her house 4 days earlier due to fall from her height. There were no symptoms in the first $48 \mathrm{~h}$, but after this period, the above-mentioned symptoms and signs appeared. She also reported history of maxillary sinusitis, with no symptoms or treatment at the moment of trauma.

Results of blood test, including coagulation 

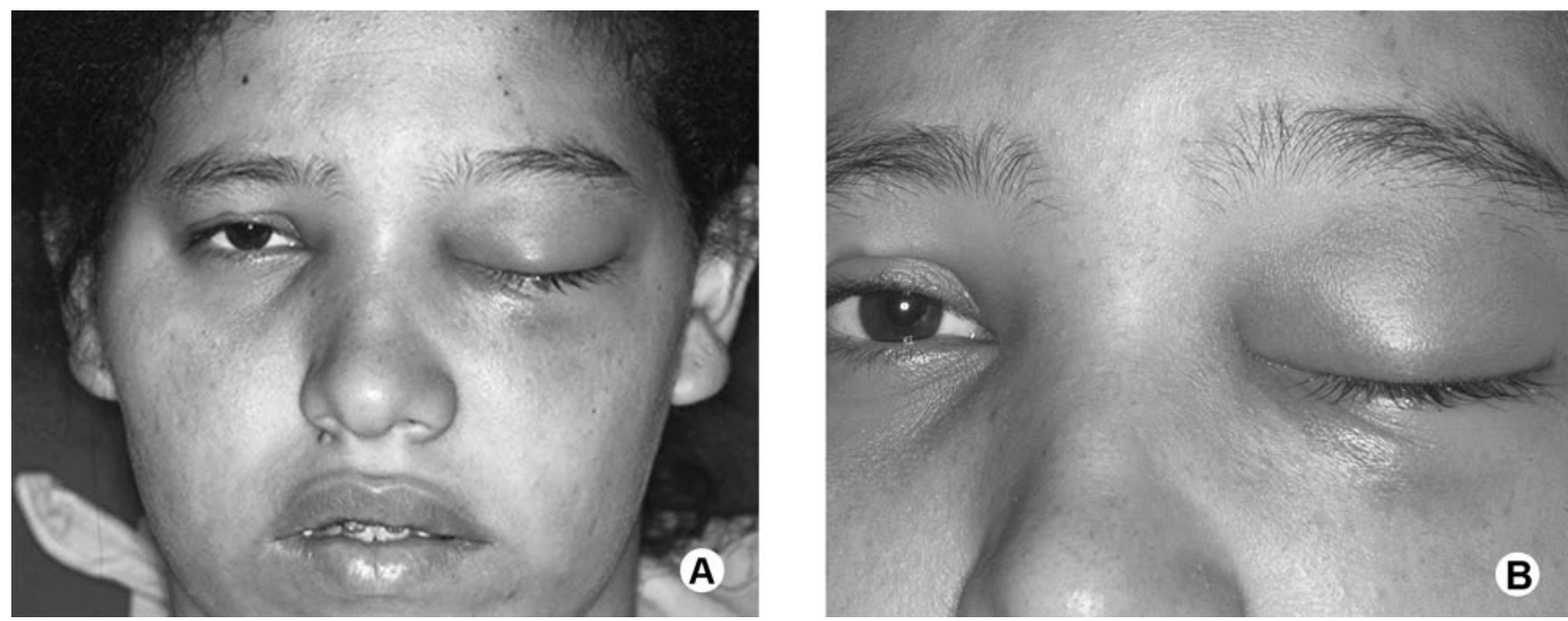

Figure 1. Preoperative photographs. $\mathrm{A}=$ Frontal view in the initial exam; $\mathrm{B}=$ Close view showing periorbital swelling and redness, ptosis and proptosis on the left side.
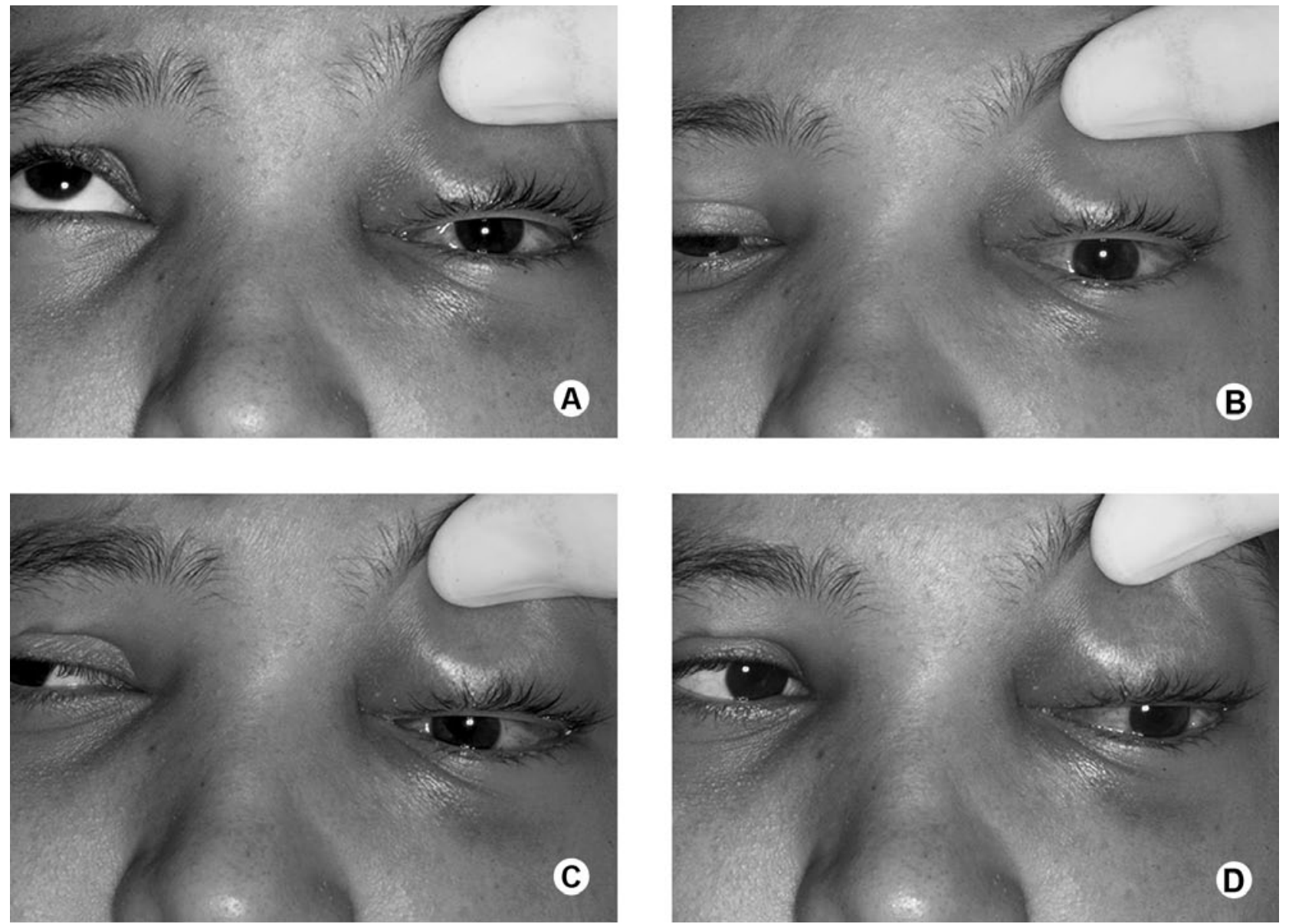

Figure 2. Ocular motility during the initial exam showing limitation of ocular movement upwards (A), downwards (B), to the right (C) and to the left (D). 
studies, were within normal ranges except for a mild leukocytosis (14.4 x $10^{9}$ cells per liter). Computed tomography scan showed proptosis with considerable soft tissue swelling on the left side. Furthermore, all sinuses on the left side and the maxillary sinus on the right side were filled with fluid (Fig. 3). No fracture was observed in the facial skeleton, including the zygomatic-orbital complex. Therefore, the diagnosis of left orbital abscess secondary to the facial trauma and posterior maxillary sinusitis was made.

The patient was admitted to the hospital and an antibiotic therapy was established using amoxicillinclavulanate intravenously ( $1 \mathrm{~g} \mathrm{6/6} \mathrm{h).} \mathrm{At} \mathrm{the} \mathrm{next} \mathrm{day,}$ the patient was subjected to incision and drainage under general anesthesia in the operation room. The purulent secretion into the left orbit and maxillary sinus was drained thought extra and intraoral blunt dissection, respectively (Fig. 4). The orbit was approached thorough both eyelids, upper (Fig. 4A) and lower (Fig. 4B) and the maxillary sinus was reached only through the CaldwellLuc approach (Fig. 4C). While Penrose's drains were maintained for 2 days in the orbital approaches none was utilized in intraoral approach (Fig. 5).

The postoperative period was uneventful and the rapid improvement of symptoms was remarkable. Visual acuity and ocular motility returned to the normal ranges in the course of 2 days. The patient was discharged 5 days after the surgical procedure and oral amoxicillinclavulanate $(1 \mathrm{~g} 6 / 6 \mathrm{~h})$ was prescribed for 7 days. After 12 postoperative days, the patient presented with significative improvement in the ptosis and proptosis, acceptable scars (Fig. 6), and normal ocular motility (Fig. 7).
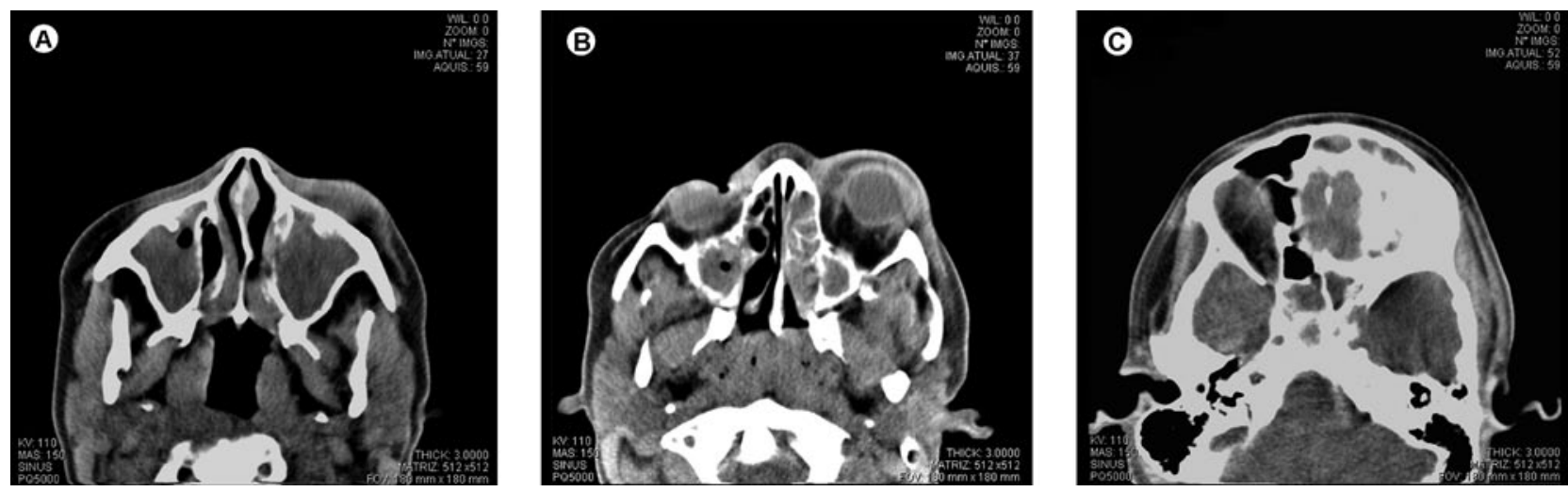

Figure 3. Preoperative CT scan in axial view demonstrating on the left side sings of acute sinusitis in the maxillary (A), ethmoidal (B) and frontal $(\mathrm{C})$ sinuses. Proptosis and soft tissue swelling is also shown.
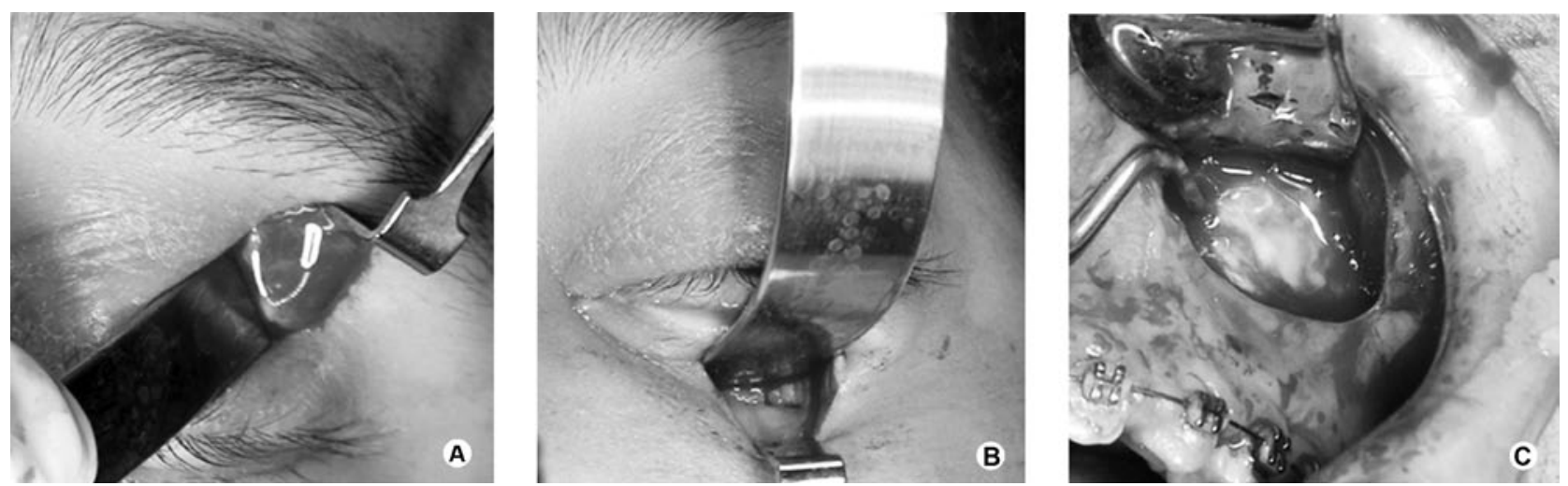

Figure 4. Intraoperative photographs. The orbit was drained superiorly (A) as well as inferiorly (B). In addition, the maxillary sinus was exposed through Caldwell-Luc approach (C). 


\section{DISCUSSION}

Orbital cellulitis and abscess occur most commonly as a result of ethmoidal and/or maxillary sinusitis. In the pediatric population, up to $90 \%$ with orbital cellulitis have paranasal sinusitis, and nearly half have multiple sinus involvement (9). Orbital cellulitis and abscess have been rarely described after nasal or orbital fractures with preexisting sinusitis (10). Computerized tomography scanning remains the imaging study of
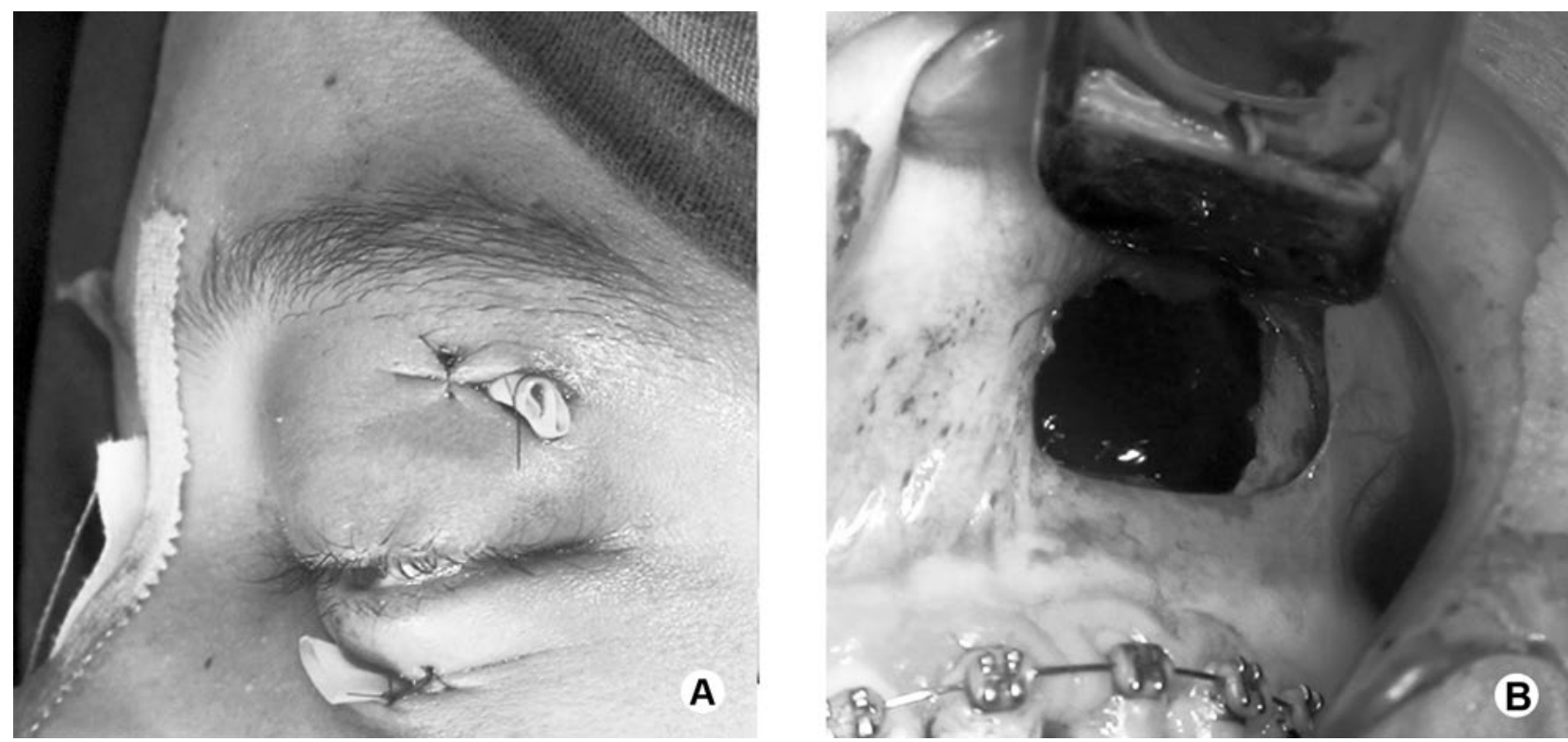

Figure 5. Intraoperative photographs. A = Extraoral view showing the Penrose's drains in position. B= Intraoral view before suture.
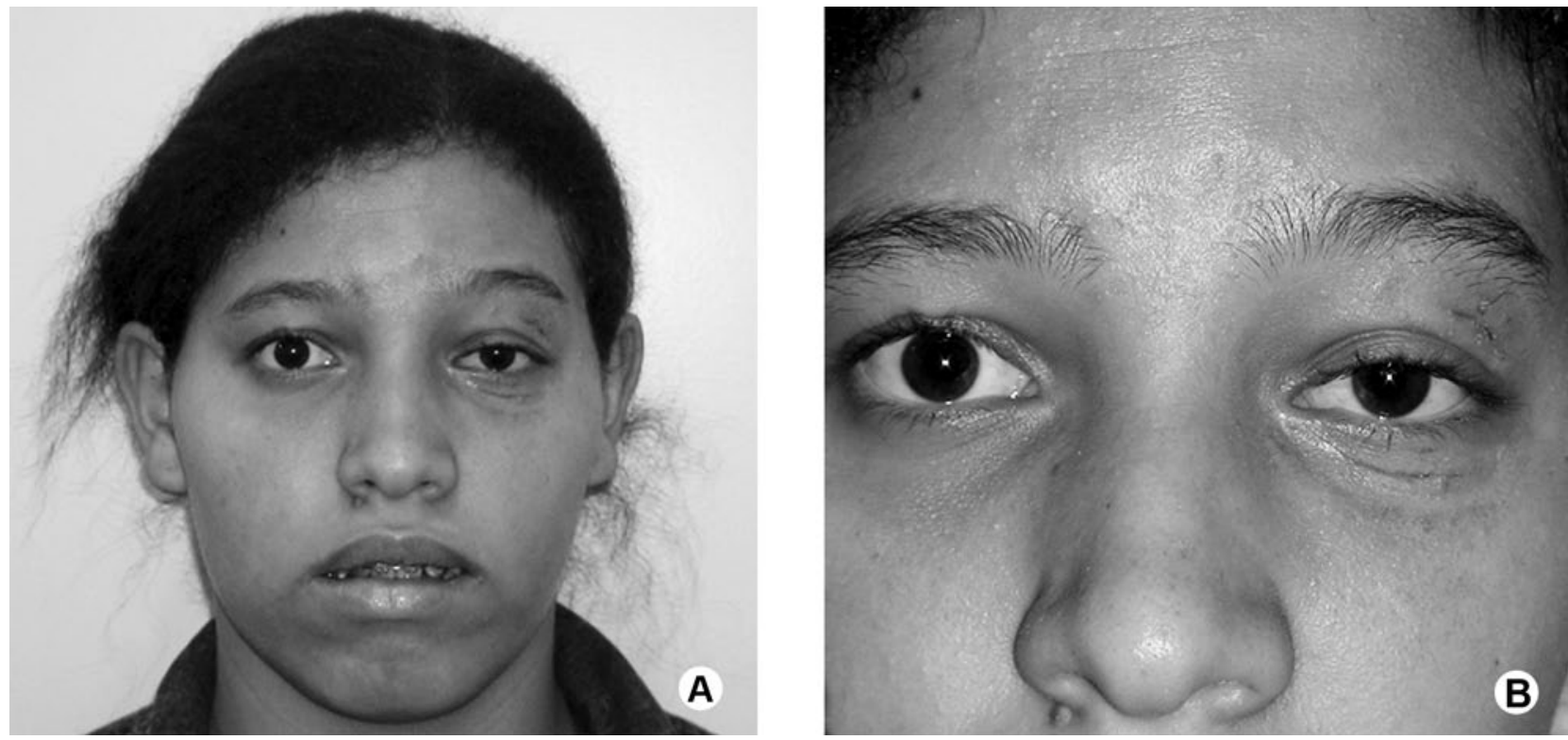

Figure 6. Postoperative photographs. $\mathrm{A}=$ Facial appearance on the 12 th postoperative day. $\mathrm{B}=$ Close view showing significant improvement on the left periorbital area. 
choice for localization of sinus infection and grading of orbital inflammation (11).

In 1970, Chandler et al. (12) introduced a classification system for orbital infection consisting of preorbital cellulitis (stage I), orbital cellulitis (stage II), subperiostal abscess (stage III), orbital abscess (stage IV), and cavernous sinus thrombosis (stage V). For the authors, the stages I and II can be managed medically
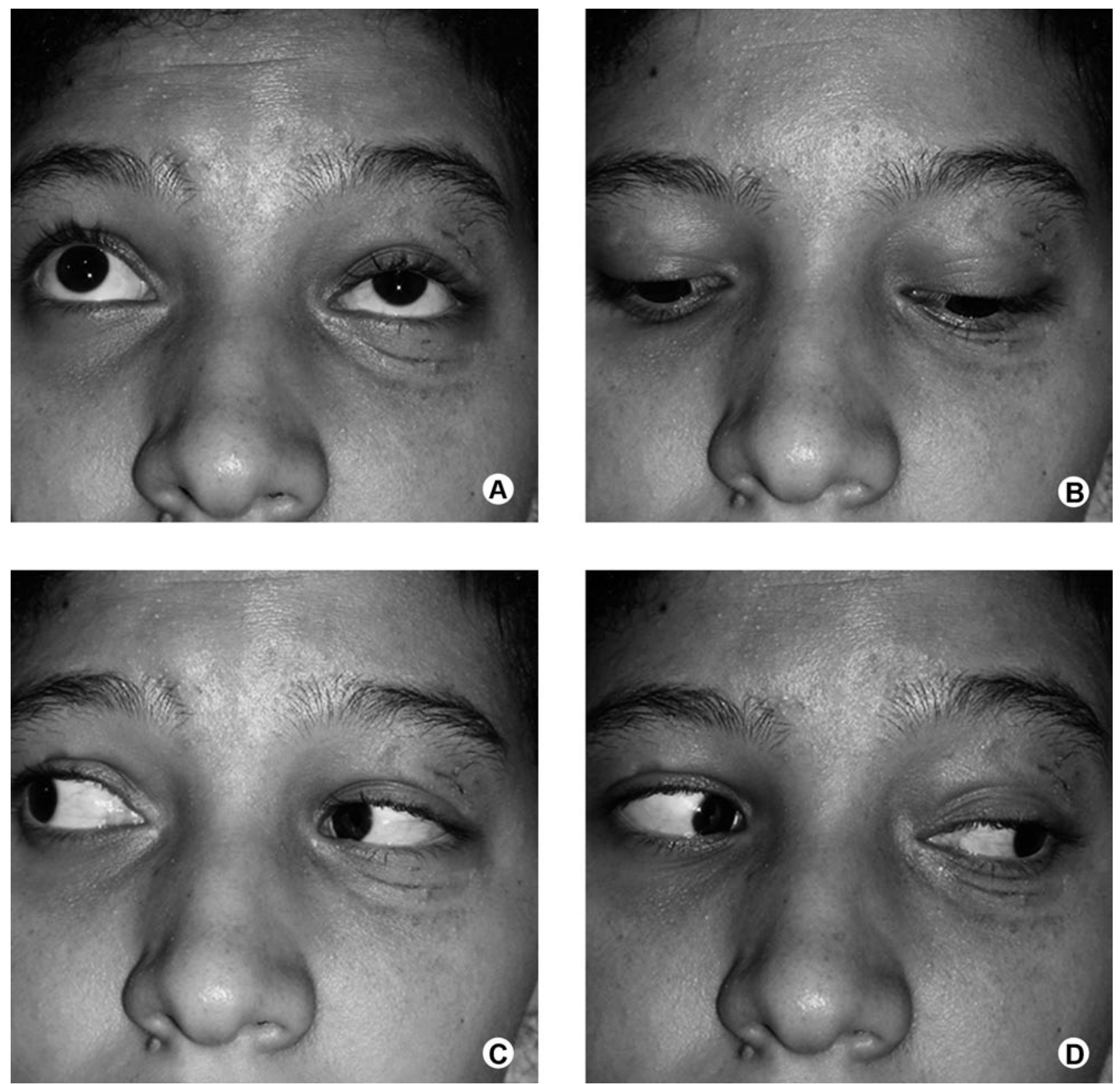

Figure 7. Ocular motility exam during 12th postoperative day showing normal ocular movement upwards (A), downwards (B), to the right $(\mathrm{C})$ and to the left (D). while stages III, IV, and V should be treated surgically through drainage. The surgical intervention is highly recommended in cases of orbital cellulitis or abscess with compromised optic nerve function and when orbital infection fails to respond to medical management $(13,14)$.

Numerous reports in the medical literature have dealt with the bacteriological aspect of the acute orbit. 
A review of the literature shows that Staphylococcus aureus, Streptococci pneumonie and Hemophilus influenza are predominantly responsible for these infections (15-17). Appropriate and effective selection of the antibiotic regimen is recommended to avoid progressive exacerbation of the infection. Antibiotic therapy should be administered intravenously to ensure a rapid and reliable plasma concentration (13). If no improvement occurs within $36 \mathrm{~h}$, the antibiotic therapy must be reconsidered without delay (3).

The surgical therapy should be performed under general anesthesia to ensure adequate exploration and drainage of the cellulitis or abscess. The surgical approaches to the orbit resemble those used during open reduction of periorbital fractures. The main purpose of the surgery is to drain any purulent material and release the intraorbital pressure. Surgery may include orbital decompression with or without abscess drainage and drainage of affected sinuses $(3,13,14)$. Some authors recommend drainage via maxillary sinus, especially in cases where the maxillary sinus is primarily involved (14). The aim of the treatment is the recovery of visual acuity and avoidance of the spread of the orbital infection with possible fatal complications, such as cavernous sinus thrombosis, meningitis, subdural empyema, and brain abscess (18).

In conclusion, the abscess of the orbit is a surgical emergency in patients whose impairment of vision or ocular symptoms cannot be controlled with medical therapy using antibiotics. Early and prompt diagnosis and treatment before severe loss of visual acuity is necessary to rescue the vision.

\section{RESUMO}

Este artigo apresenta um caso de abscesso agudo em cavidade orbitária, após 2 dias de trauma facial, sem a presença de fratura óssea, ocorrido em uma mulher da raça negra com 20 anos de idade. Os sintomas se intensificaram nas últimas $24 \mathrm{~h}$ com o desenvolvimento de distúrbios visuais do tipo diplopia e fotofobia. Durante exame clínico foi constatado a presença de febre, edema e eritema periorbitário, ptose, proptose e limitação de movimentação ocular para cima, baixo, lado direto e esquerdo. A tomografia computadorizada evidenciava proptose associada a edema considerável, dos tecidos moles no lado esquerdo da face, sem fratura do complexo zigomático-orbitário. A internação hospitalar e o início da antibioticoterapia endovenosa foram realizados, e o tratamento cirúrgico de incisão e drenagem do abscesso sob anestesia geral foi conduzido, sendo realizado por meio de incisão na pálpebra superior e inferior para acesso a cavidade orbitária e por acesso de Caldwell-Luc para o seio maxilar. No pós-operatório imediato foi observada rápida melhora dos sintomas inicialmente relatados pela paciente. Após 2 dias da intervenção cirúrgica foi observado melhora na movimentação ocular e na acuidade visual, retornando ao normal. No décimo segundo dia pós-operatório, a paciente apresentou melhora significativa com relação à ptose palpebral e a proptose, com adequado processo de cicatrização.

\section{REFERENCES}

1. Guindi GM. Acute orbital cellulitis: a multidisciplinary emergency. Br J Oral Surg 1983;21:201-207.

2. Davis JP, Stearns MP. Orbital complications of sinusitis: avoid delays in diagnosis. Postgrad Med J 1994;70:108-110.

3. Blake FAS, Siegert J, Gbara A, Wedl J, Schmelzle R. The acute orbit: etiology, diagnosis, and therapy. J Oral Maxillofac Surg 2006;64:87-93.

4. Janakarajah N, Sukumaran K. Orbital cellulitis of dental origin: case report and review of the literature. Br J Oral Maxillofac Surg 1985;23:140-145.

5. Wysluch A, Maurer P, Ast J, Kunkel M. Orbital complications due to an acute odontogenic focus in a child. A case report. Oral Surg Oral Med Oral Pathol Oral Radiol Endod 2009;107:e39-42.

6. Goodyear PW, Firth Al, Strachan DR, Dudley M. Periorbital swelling: the important distinction between allergy and infection. Emerg Med J 2004;21:240-242.

7. Sakamoto H, Karakida K, Otsuru M, Arai M, Shimoda M. A case of brain abscess extended from deep fascial space infection. Oral Surg Oral Med Oral Pathol Oral Radiol Endod 2009;108:e21-25.

8. Johnson DP, Knoop KJ. Images in emergency medicine. Ann Emerg Med 2006;47:134-135.

9. Ferguson MP, McNab AA. Current treatment and outcome in orbital cellulitis. Aust N Z J Ophthalmol 1999;27:375-379.

10. Paterson AW, Barnard NA, Irvine GH. Naso-orbital fracture leading to orbital cellulitis, and visual loss as a complication of chronic sinusitis. Br J Oral Maxillofac Surg 1994;32:80-82.

11. Howe L, Jones NS. Guidelines for the management of periorbital cellulitis/abscess. Clin Otolaryngol Allied Sci 2004;29:725-728.

12. Chandler JR, Langenbrunner DJ, Stevens ER. The pathogenesis of orbital complications in acute sinusitis. Laryngoscope 1970;80:1414-1428.

13. Harris GJ. Subperiosteal abscess of the orbit. Age as a factor in the bacteriology and response to treatment. Ophthalmology 1994;101:585-595.

14. Simon GJB, Bush S, Selva D, McNab AA. Orbital cellulitis: a rare complication after orbital blowout fracture. Ophthalmology 2005;112:2030-2034.

15. Moloney JR, Badham NJ, McRae A. The acute orbit. Preseptal (periorbital) cellulitis, subperiosteal abscess and orbital cellulitis due to sinusitis. J Laryngol Otol Suppl 1987;13:1-18.

16. Ikeda K, Oshima T, Suzuki H, Kikuchi T, Suzuki M, Kobayashi T. Surgical treatment of subperiosteal abscess of the orbit: Sendai's ten-year experience. Auris Nasus Larynx 2003;30:259-262.

17. Brook I. Microbiology of acute sinusitis of odontogenic origin presenting with periorbital cellulitis in children. Ann Otol Rhinol Laryngol 2007;116:386-388.

18. Allan BP, Egbert MA, Myall RW. Orbital abscess of odontogenic origin. Case report and review of the literature. Int J Oral Maxillofac Surg 1991;20:268-270. 